\title{
ACE polymorphism in asthmatic patients
}

\author{
Margarida Cortez ${ }^{*}$, Andreia Matos², Joana Ferreira², Leonor Lopes², Angela Gil², Manuel Bicho² \\ From EAACI International Severe Asthma Forum (ISAF 2012) \\ Gothenburg, Sweden. 11-13 October 2012
}

\section{Background}

The aim of the this study was to analyse if there is an association between angiotensin converting enzyme (ACE) insertion/deletion (I/D) polymorphism (287 base pairs, on chromosome 17q23, intron 16 (rs4340)) with asthma severity. ACE plays a vital role in the renin-angiotensinsystem (RAS) which regulates blood pressure by converting angiotensin I into a powerful vasoconstrictor angiotensin II, that also has an important role in airway remodeling and in inactivation of bradykinin and tachykinins. The signaling pathways, related with this polymorphism regulating the cytokine production by $\mathrm{T}$ cells, could induce a different $\mathrm{Th}$ profile modulating the immune response in asthma.

\section{Methods}

Asthmatic patients: $\mathrm{n}=68$; were compared with a control group of $n=204$ healthy blood donors. The insertion/ deletion (I/D) polymorphism was determined by PCRpolymerase chain reaction. Control of asthma assessed by validated instrument (ACQ7 and PAQLQ). Statistical analysis was performed with PASW 18, establishing a significance level of $\mathrm{p}<0.05$.

\section{Results}

The mean age of the 68 asthmatics was $39.95 \pm 18.9$ years; 42 females and 26 males; 66 Caucasians and 2 non-Caucasians; 57 atopic and 11 nonatopic. The mean age of the control-group ( $\mathrm{n}=204)$ was $40.97 \pm 12.08$ years; 69 females and 135 males. In asthmatics the frequencies of the D-Allele (ACE-D) is 0.647 and of the I-Allele (ACE-I) is 0.353 ; in controls: 0.868 and 0.132 respectively. There is statistical difference between these groups $(\mathrm{p}=0.008)$. Genotypes in the asthmatics- DD: 44.1\%; ID: 20.6\%; II: $35,3 \%$; in control group- DD: $48 \%$; ID: $38.8 \%$; II: $13.2 \%$. There is statistical difference between these groups $(\mathrm{p}=0.000)$. The II genotype was more frequent in the asthmatics when compared with controls being the

${ }^{1} \mathrm{CHLN}-\mathrm{HSM}$, Portugal

Full list of author information is available at the end of the article risk associated 3.576 (CI 95\% [1.883 - 6.799], ( $\mathrm{p}=0.000)$. In asthmatics, there is no statistical differences in genotype frequencies $(\mathrm{p}>0.05)$ between: atopics and non atopics; controlled and uncontrolled asthma; males and females; and in the different age-groups.

\section{Conclusions}

The role of ACE insertion/deletion (I/D) polymorphism, in asthmatic patients is a controversy risk factor to the severity of asthma, but we concluded that the II genotype is more prevalent in the asthmatics from this hospital-based population.

\section{Author details}

${ }^{1}$ CHLN-HSM, Portugal. 'Lisbon Medical School, Genetic Department, Portugal.

Published: 3 May 2013

\section{doi:10.1186/2045-7022-3-S1-P14}

Cite this article as: Cortez et al:: ACE polymorphism in asthmatic

patients. Clinical and Translational Allergy 2013 3(Suppl 1):P14.

\section{Submit your next manuscript to BioMed Central and take full advantage of: \\ - Convenient online submission \\ - Thorough peer review \\ - No space constraints or color figure charges \\ - Immediate publication on acceptance \\ - Inclusion in PubMed, CAS, Scopus and Google Scholar \\ - Research which is freely available for redistribution

